\title{
Trust-Based Determinants of Future Intention to Use Technology
}

\author{
Joanna Ejdys \\ Professor, Faculty of Engineering Management, j.ejdys@pb.edu.pl \\ Bialystok University of Technology, 45A, Wiejska Street, 15-351 Bialystok, Poland
}

\begin{abstract}
$\mathrm{I}$ $t$ is widely recognized that one of the factors determining current and future socioeconomic development is the level of digitalization shaping a new type of society, the information society. One area of ICT application within information society is e-Government. A relatively low level of development of e-Government services in Poland was behind the search for the causes of this phenomenon. Among many technological, organizational, human, economic, social, and cultural factors determining the development of e-Government, many researchers indicated trust as one of the most critical factors. Mistrust is perceived as a basic limitation for the implementation of e-Government solutions. The author's object of interest was e-Declaration technology, which enables the electronic filling and sending of tax returns to the tax authorities. This article investigates the relationship between the features of technology users and their trust in the e-Declaration technology and their future intention to use the technology. The researched user traits refer to their general trust, overall trust in technology and science development, and their experience and trust in

the internet. Data was collected with the use of the CATI (Computer Assisted Web Interview) technique. Altogether, 1,054 completed questionnaires were selected, containing $100 \%$ of the answers. The regression analysis was preceded by an analysis of correlations between variables. The hypotheses were confirmed using the Kruskal-Wallis non-parametric test. The obtained results confirmed positive relationships between Trust in e-Declaration (T) and all tested constructs: General Trust (GT), overall Trust in Science and Technology (TST), Trust in the Internet (TinI) and Internet Experience (IE). Results also confirmed the positive impact of Trust in e-Declaration $(\mathrm{T})$ on the Future Intention (FI) to use the technology. In the adopted regression model, Trust in the Internet was recognized as a key factor in the success of e-Government development. Therefore, the Polish government, which offers solutions in the field of e-Government and wants to increase trust in the technology as well as extend future adaptations of the technology, should concentrate on building trust in the internet and the development of technology and science in general.
\end{abstract}

Keywords: user intentions; trust in technology; e-Government; general trust; Internet experience; trust in the Internet

Citation: Ejdys J. (2020) Trust-Based Determinants of Future Intention to Use Technology. Foresight and STI Governance, vol. 14, no 1, pp. 60-68. DOI: 10.17323/25002597.2020.1.60.68 
$\mathrm{T}$ The dynamic development of technologies and their increasingly widespread applications always raise questions about the future scope of the use of a given technology [Nazarko, 2017; Nazarko et al., 2017]. This question seems particularly important at the stage of implementation of new emerging technologies [Hengstler et al., 2016]. The answer to the question "What will the future scope of technology use be?" will be of interest to the producers and users of technologies [Halicka, 2018]. To describe technology acceptance processes, many theoretical models have been developed, such as the Technology Acceptance Model (TAM), Unified Theory of Acceptance and Use of Technology (UTAUT) and D\&M IT Success model. The most popular, the Technology Acceptance Model (TAM), was developed by Davis [Davis, 1985]. The main premise of the model was that the use of (technical) systems depended upon the motivation of their users, which was influenced by other external features and capabilities of the system [Davis, 1985]. Over the past 30 years, the original TAM model underwent many modifications, in which the authors added further variables. Many other researchers have introduced a variable of trust in technology into models explaining the current and future use of technology [Gefen, 2004; Gefen et al., 2003; Wu et al., 2011]. Also, research in the UTAUT model confirms that the most frequently considered external variables for the model include trust in technology [Williams et al., 2015]. As proposed by Tams et al., trust in technology can be understood as beliefs about the desirable or beneficial features of a technology [Tams et al., 2018].

Researchers have shown that trust in technology influences various technology acceptance levels, such as online recommendation agents, business information systems, mobile-commerce portals, and knowledge management systems [Lankton et al., 2015]. Lack of trust is one of the most important barriers to e-service adoption, especially when personal or financial information is involved [Pavlou, Fygenson, 2006; Belanger, Carter, 2008].

Trust in technology can be considered at different stages of the technology acceptance process. Two types of trust can be remarked upon: pre-use trust before the application or implementation of the technology and post-use trust which is considered after the application or implementation of the technology [Rousseau et al., 1998; McKnight et al., 1998; Komiak, Benbasat, 2008; Lin et al., 2014]. Pre-use trust influences the intentions of potential users to deploy the technology, while postuse trust influences the intentions of potential users to continue to use the technology. According to the research conducted by many authors, trust as a constructor in technology acceptance models was treated as a determinant of the attitude towards the use of the technology [Gefen, 2004; Gefen et al., 2003; Lean et al., 2009]. Research conducted by Wu et al. [Wu et al., 2011] confirmed the existence of statistically important relationships between trust and attitudes.
Meng and his colleagues [Meng et al., 2008] studied factors determining trust in technology in mobilecommerce. The model consisted of four categories of variables determining trust including general trust, trust in mobile technologies in general, trust in the seller measured by ability (competence), reliability, and friendliness, and institutional trust [Meng et al., 2008]. The author's model was not subject to empirical verification.

Chen et al. were interested in a technological explanation in the field of e-Government. As factors determining trust in technology, the authors studied: general trust in technology, trust in the administration, trust in government websites, and previous user experience in using e-Government solutions [Chen et al., 2015].

Alzahrani et al. [Alzahrani et al., 2017] developed a theoretical model, in which, among the determinants of trust in e-Government, they indicated user experience, general trust, internet experience, and education.

Research related to the determinants of trust allowed the author to distinguish four groups of factors: (i) institutional-organizational factors, (ii) technological factors, (iii) factors related to user characteristics, and (iv) the environment. Authors are often interested in the determinants of trust that reflect the characteristics of technology users. The author of this article intends to limit the determinant without referring to the factors connected with the functionality and usefulness of technologies. Among the variables that are of interest to the author and which determine trust in a particular technology are general trust, trust in science and technology, and trust and experience in using the Internet. Moreover, the model includes relations between trust in technology and the future intentions of users.

The literature study carried out allowed for defining the following scientific questions: How do the characteristics of technology users determine the trust of Polish society toward e-Government and future the adoption of e-Government?

The aim of the article is to examine the relationship between the characteristics of technology users and their trust in technology and the future intention to use the technology. The researched features of the users refer to the general trust of the users and the general trust in the development of technology and science or trust in the Internet.

\section{Literature Review and Theoretical Model}

From a sociological point of view, general trust (social - the object of interest of sociologists) will affect trust in a specific technological solution. General trust is the belief that, as a rule, people are trustworthy. Research conducted by Chopra and Wallace 
shows that every human being is characterized by a different level of general trust, conditioned by cultural and sociological factors [Chopra, Wallace, 2003]. Trust propensity (general trust) reflects an ability to rely upon others in different situations [Kumar et al., 2017]. Zhou [Zhou, 2011] indicated that users with high general trust tend to have positive inclinations towards new technological solutions. Research conducted by Lee and Turban confirmed the moderating effect of individual general trust (individual trust propensity) on consumer trust towards internet shopping [Lee, Turban, 2001]. Lippert and Swiercz also included general trust as one of the characteristics that affect trust in technology [Lippert, Swiercz, 2005]. Agag and El-Masry tested relationships between general trust and consumer trust towards online travel websites [Agag, El-Masry, 2017], and proved the existence of positive relationships between the mentioned variables. Considering the above, the authors formulated the following hypothesis:

Hypothesis (H1). General trust (GT) will positively influence the Trust in e-Declaration technology $(T)$

In addition to general trust that reflects a person's willingness to rely upon others in a particular situation, the relationship between technology users and science and technology developments, in general, seems to be very important as well. Not always a high level of general trust coincides with a belief in the potential of technology development to improve human life. The results of the World Values Survey ${ }^{1}$ confirm that societies with a relatively high level of general trust already have a much lower level of trust in the positive impact of technology and science on improving life and the world in general. For example, in the Scandinavian countries (Finland, Sweden, Norway), where the level of general social trust is very high $(58.0 \%, 60.1 \%$, and $73.7 \%$ of the population of these countries, respectively, believe that "Most people can be trusted"), the belief that "Science and technology are making our lives healthier, easier" is already much lower. A total of $36.0 \%$ of respondents in Finland, 33.5\% in Norway and 38.0\% in Sweden believe in this statement, which at the level of 8-10. In contrast, only $22.2 \%$ of the population in Poland positively reacted to the statement "Most people can be trusted" and as many as $61.2 \%$ of the population assessed the statement "Science and technology are making our lives healthier, easier" at the level of 8 to 10. Therefore, the author proposed an additional variable reflecting the belief of technology users in the very fact that science and technology can make our lives better, healthier, more comfortable, turning the world into a better place. Considering the above, the authors formulated the following hypothesis:
Hypothesis (H2). General trust in science and technology (TST) will positively influence the Trust in eDeclaration technology $(T)$

The internet - being the infrastructure of e-Government - is still a source of uncertainty for some users, and a lack of trust would affect the use of e-services [Carter, Bélanger, 2005]. Voutinioti [Voutinioti, 2013] also included the variable of Internet trust in the UTAUT model and demonstrated a statistically significant link between trust and user intentions in the use of e-Government solutions. Also, Lee and Turban [Lee, Turban, 2001], while building a model of trust in online shopping, considered the variable of internet trust and studied its impact upon trust in online shopping technology. Agag and El-Masry tested the relationships between consumer experience and consumer trust towards online travel websites [Agag, El-Masry, 2017]. Considering the above, the authors formulated the following two hypotheses:

Hypothesis (H3). Trust in Internet (TinI) will positively influence the Trust in e-Declaration technol$\operatorname{og} y(T)$

Hypothesis (H4). Internet experience (IE) will positively influence the Trust in e-Declaration technology $(T)$

In the face of many studies on the factors shaping trust in technology, fewer research publications examine how and why trust determines subsequent adoption behaviors [Tams et al., 2018]. From a psychological point of view, trust can help the user to exclude undesirable, unexpected technology performance and, thus, increase intentions to use the technology [Gefen et al., 2003]. Developing their model for the adoption maturity of e-Government solutions, Joshi and Islam pointed out that trust was an important element for the sustainable adoption of e-Government solutions [Joshi, Islam, 2018]. Also, the research conducted by Hernandez-Ortega proved that trust in technology positively influences the intentions to continue using technology [Hernandez-Ortega, 2011]. Weerakkody et al. [Weerakkody et al., 2013] confirmed the previous conclusions regarding the positive impact of trust upon the adoption and continued use of electronic government services. According to Agag and El-Masry, trust influences consumer intentions to purchase a trip online [Agag, El-Masry, 2017]. Similar results were obtained by Kumar et al. studying mobile banking technology [Kumar et al., 2017]. Kaur and Rampersad indicated that trust in driverless cars played a crucial role in the adaptation process of such technology [Kaur, Rampersad, 2018]. Research conducted by Khalilzadeh et al. [Khalilzadeh et al., 2017] in relation to near-field communication mobile pay- 
ment technologies did not show a statistically significant relationship between trust and intentions of user behavior [Khalilzadeh et al., 2017]. Voutinioti [Voutinioti, 2013] demonstrated statistically significant links between trust and user intentions in the use of e-Government solutions. Different results concerning the relations between the studied constructs (trust and intentions) indicate that the type of technology determines the character of these relations. Considering the above, the author formulated the following hypothesis:

Hypothesis (H5). Trust in e-Declaration technology (T) will positively influence the future intention to use e-Declarations (FI)

Figure 1 presents the conceptual model that reflects links between all theoretical variables and hypotheses.

\section{Research Methodology \\ Data}

The conducted research focuses on the e-Declaration - an electronic technology for submitting tax returns. This service and ICT tools were created by the Ministry of Finance. In 2018, the inhabitants of Poland filled more than 11 million tax returns electronically.

Research data was collected using a survey method. The conducted research was quantitative and allowed for verifying the accepted research hypotheses. The process of data collection was carried out with the use of the CAWI technique.

The survey respondents were Polish residents who had used the e-Declaration system within the last two years, i.e. sent their tax return via the Internet. The research process was carried out by employees of the Ministry of Finance (MF). As part of this collabora-

\section{Figure 1. Conceptual Model}

Characteristics of

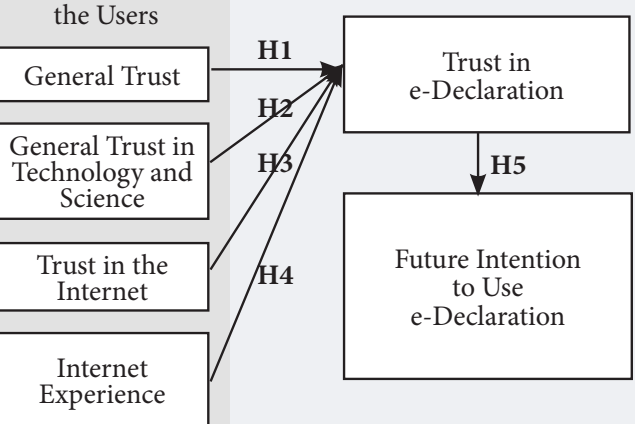

Source: elaborated by the author. tion, the author developed a research questionnaire, which was validated by employees of the Ministry of Finance. The task of the Ministry of Finance was to randomly send an e-mail message with a link to the electronic survey to taxpayers registered in the MF database.

The study assumed the acquisition of a representative sample, which allowed the results to be generalized for the entire population. The minimum sample size was 1,067 , assuming a confidence level of $0.95(1-\alpha)$ and a maximum permissible error of $3 \%$ calculated for the general population of about 11 million taxpayers using the e-government system. The survey was conducted in May 2018. Successive (due to the technical limitations of the mailbox) lots of e-mails from the dedicated account ankietaPB@mf.gov.pl, allowed for the ongoing monitoring of the status of survey completion. As soon as 1,067 completed questionnaires were received, the e-mail dispatch was suspended. After the analysis of the returned questionnaires and the elimination of forms with data gaps, 1,054 completed questionnaires containing $100 \%$ of answers were selected.

Of the 1,054 respondents, 484 (45.9\%) were women, and $570(54.1 \%)$ were men. The share of respondents aged $26-40$ was $52.1 \%$ ( 549 persons), followed by $29.5 \%$ (311 persons) aged $41-60$. The number of respondents in the age groups of 18-25 and over 61 years of age constituted about $9 \%$ of the respondents each $(9.1 \%-96$ persons and $9.3 \%-98$ persons $)$.

\section{Measures}

Since some constructs could not be directly observed, a series of measures were used in each case. Based on the literature study, four items have been identified for measuring Trust in the e-Declaration, and two for the Future Intention to Use (Table 1). To measure the general trust and trust in science and technology, questions included in the research carried out by the Institute for Comparative Survey Research as part of the World Values Survey were used. All constructs were measured using a seven-point Likert scale to access the degree to which a respondent agreed or disagreed with each of the items $(1=$ totally disagree; $7=$ totally agree). Cronbach's alpha coefficients of the constructs were used to verify the reliability of the scale and proved the acceptable reliability of the scale ranging from 0.738 to 0.926 (Table 1). Descriptive statistics and composite reliability for the constructs and items are presented in Table 1.

The mean value of the indicated constructs is shown in Figure 2. The low evaluation of general (social) trust coincides with the results of global research, according to which Polish society belongs to countries characterized by a relatively low level of social trust (World Values Survey). 


\section{Table 1. Constructs and Items}

\begin{tabular}{|c|c|c|c|c|}
\hline Constructs (source) & Abbr. & Observed variables (Items) & Mean & $\begin{array}{l}\text { Cronbach's } \\
\text { alpha }\end{array}$ \\
\hline $\begin{array}{l}\text { General Trust } \\
\text { (World Values Survey) }\end{array}$ & GT & Most people can be trusted & 3.83 & \\
\hline \multirow{2}{*}{$\begin{array}{c}\text { General Trust } \\
\text { in Science and } \\
\text { Technology } \\
\text { (World Values Survey) }\end{array}$} & TST1 & $\begin{array}{l}\text { Science and technology are making our lives healthier, easier, and } \\
\text { more comfortable }\end{array}$ & 6.27 & \multirow{2}{*}{0.760} \\
\hline & TST2 & The world is better off because of science and technology & 5.78 & \\
\hline $\begin{array}{l}\text { Trust in the } \\
\text { Internet }\end{array}$ & TinI & I generally trust the solutions offered by the Internet & 4.70 & \\
\hline Internet Experience & IE & I have extensive experience in using the Internet & 6.47 & \\
\hline \multirow{4}{*}{$\begin{array}{c}\text { Trust in } \\
\text { e-Declaration } \\
\text { [Al-Hujran et al., } \\
\text { 2015; Colesca, 2009; } \\
\text { Lippert, 2007] }\end{array}$} & $\mathrm{T} 1$ & The e-Declaration system works according to my expectations & 5.49 & \multirow{4}{*}{0.926} \\
\hline & $\mathrm{T} 2$ & $\begin{array}{l}\text { I am convinced that the e-Declaration system will function } \\
\text { properly when I need it }\end{array}$ & 5.38 & \\
\hline & T3 & I can rely on the e-Declaration system & 5.69 & \\
\hline & $\mathrm{T} 4$ & The e-Declaration system is predictable and unchanged & 5.42 & \\
\hline \multirow[b]{2}{*}{$\begin{array}{l}\text { Future Intention to } \\
\text { Use e-Declaration } \\
\text { [Kurfal et al., 2017; } \\
\text { Al-Hujran et al., } \\
\text { 2015; Venkatesh et } \\
\text { al., 2012; Bélanger, } \\
\text { Carter, 2008; } \\
\text { Carter, Bélanger, } \\
\text { 2005] }\end{array}$} & FI1 & I intend to make greater use of the e-Declarations system & 5.13 & \multirow[b]{2}{*}{0.738} \\
\hline & FI2 & I intend to make greater use of e-Government services & 5.61 & \\
\hline
\end{tabular}

The structure of the assessments of the variables is presented in Figure 3.

In the case of the variable Internet Experience (IE), as many as $94.5 \%$ of respondents answered on a scale of 5 to 7 , thus assessing their experience in this area very highly. Compared to the other observed variables, the respondent assessments of the variable Trust in the Internet (TinI) indicates a slightly lower level of trust among respondents. Almost one in four respondents $(23.6 \%)$ rated their trust in the internet from 1 to 3 on a 7-degree scale. The phenomenon observed during the research is a relatively lower level of trust in relation to a specific technology (e-Declaration: variables T1-T4) than the general trust in science and technology (TST1, TST).

\section{Research Results}

Table 2 shows variables of the Spearman's correlation coefficients. Between all constructs and Trust in the e-Declaration significant correlations were found, but the strength of the relationship was weak or moderate.

The hypotheses were confirmed using the KruskalWallis non-parametric test. The results of the test are presented in Table 3. The results of testing the relationships between constructs showed that all tested relationships were statistically significant. Trust in the e-Declaration $(\mathrm{T})$ was statistically significant due to the General Trust (GT), general Trust in Science and Technology (TST), Trust in the Internet (TinI), and Internet Experience (IE) as well. Thus, the rela- tions reflected in hypotheses $\mathrm{H} 1-\mathrm{H} 4$ were confirmed. The research also confirmed that Trust in the e-Declaration $(\mathrm{T})$ had a statistically significant impact on the Future Intentions (FI) of users, which allowed for supporting hypothesis $\mathrm{H} 5$

Correlation analysis which confirmed statistically significant relationships between the variables General
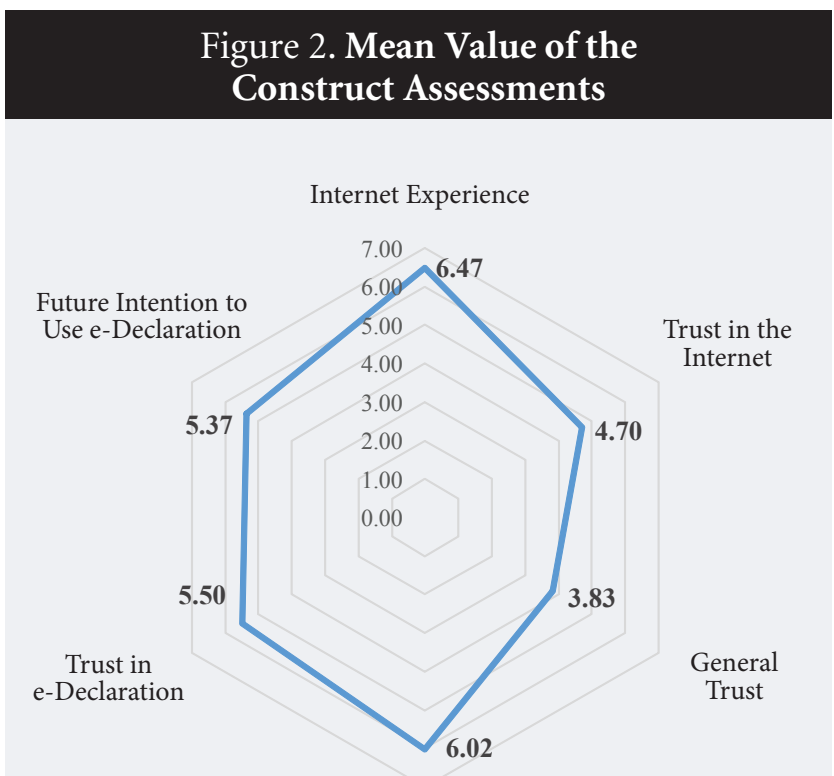

General Trust in Science and Technology

Source: elaborated by the author. 


\section{Table 2. Spearman's Correlation Coefficients}

\begin{tabular}{|l|c|}
\hline \multicolumn{1}{|c|}{ Constructs } & $\begin{array}{c}\text { Trust in } \\
\text { e-Declaration } \\
\text { Construct }\end{array}$ \\
\hline General Trust & $0.229^{* *}$ \\
\hline General Trust in Science and Technology & $0.372^{* *}$ \\
\hline Trust in the Internet & $0.456^{* *}$ \\
\hline Internet Experience & $0.167^{* *}$ \\
\hline Future Intention to Use the e-Declaration & $0.434^{* *}$ \\
\hline Source: elaborated by the author. & \\
\hline
\end{tabular}

Trust, general Trust in Science and Technology, Trust in the Internet, Internet Experience, and Trust in the e-Declaration allowed for conducting a multiple regression analysis. The constructed regression model turned out to be statistically significant $(\mathrm{F}=$ 78.373; $\mathrm{p}<0.001)$ and all predictive factors explained $23 \%$ of the dependent variable $(\mathrm{R} 2=0.23)$. Trust in the Internet $(\beta=0.25 ; t=9.897 ; p<0.001)$ and general Trust in Science and Technology $(\beta=0.23 ; \mathrm{t}=6.641$; $\mathrm{p}<0.001)$ have a significant positive impact upon the Trust in the e-Declaration.

\section{Discussion}

The correlation analysis confirmed statistically significant relationships between the Trust in the e-Declaration (T) and all the examined variables General Trust (GT), general Trust in Science and Technology (TST), Trust in the Internet (TinI), and Internet Experience (IE). At the same time, a statistically significant relationship between Trust in the e-Declaration (T) and Future Intentions to Use the e-Declaration (FI) was confirmed.

The obtained research results allowed for verifying the hypothesis $\mathrm{H} 5$ indicating a relationship between

\section{Figure 3. Mean of Construct Assessments (\%)}

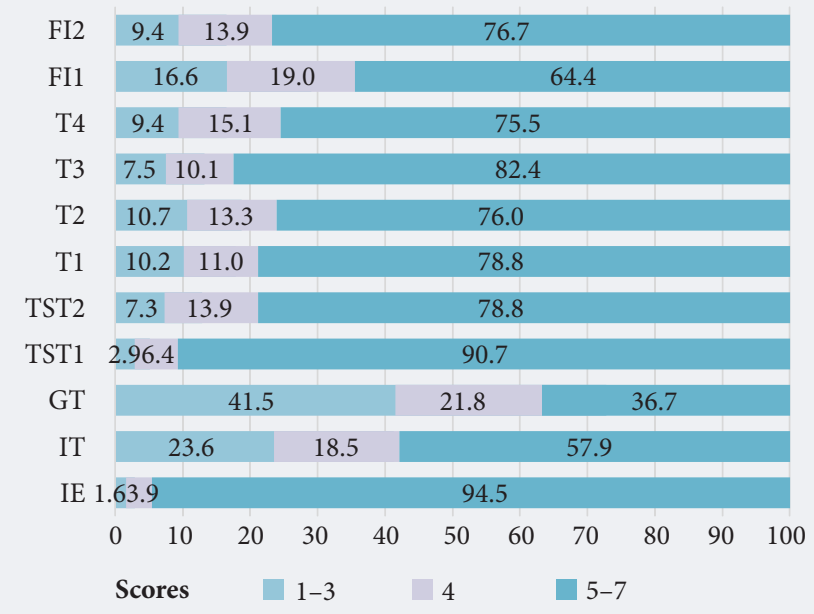

Source: elaborated by the author.
Future Intentions to use the e-Declaration and Trust in the e-Declaration. Similar results were obtained by many other researchers [Weerakkody et al., 2013; Voutinioti, 2013; Kumar et al., 2017; Kaur, Rampersad, 2018; Ejdys, Halicka, 2018].

The conducted research confirmed that the variable General Trust (GT) has a statistically significant impact on Trust in the e-Declaration $(\mathrm{T})$, which allowed one to support the hypothesis H1, which is consistent with the results of other authors [Lippert, Swiercz, 2005; Agag, El-Masry, 2017]. To some extent, this relationship may explain the relatively low level of digitalization of public services in Poland. Polish society has one of the lowest levels of social trust. In Poland, only $22.2 \%$ of the population positively reacted to the statement "Most people can be trusted", which is very low when compared to other countries such as Finland, Sweden, and Norway where the level of general social trust is very high $(58.0 \%, 60.1 \%$, and $73.7 \%$ of the population of these countries, respectively, believe that most people can be trusted) (World Values Survey). Therefore, the process of building trust in technologies determining the scope of their future use is largely determined by the general level of social trust.

The results obtained by the author confirmed a statistically significant relationship between general Trust in Science and Technology (TST) and the Trust in the e-Declaration and, thus, substantiated hypothesis $\mathrm{H} 2$. Despite the relatively low level of general trust, Polish society is characterized by a high level of trust in science and technology development as a factor that makes our lives better, healthier and more comfortable. This level of trust in science and technology also determines the trust in a specific technological solution, in this case, the e-Declaration.

In the model, two important relationships were studied between Trust in the Internet and Trust in the e-Declaration and between Internet Experience and Trust in the e-Declaration. Hypotheses H3 and H4, reflecting these relationships, were supported. The obtained results were consistent with the results of other authors. According to other researchers [Carter, Bélanger, 2005; Voutinioti, 2013], the Internet, as a new medium of technological applications, is an important factor determining trust in specific solutions, and the decisive factor is Trust in the Internet and Internet Experience possessed by its users.

The conducted regression analysis allowed for answering the question "What factors should be considered to increase the level of trust in a technology?" The highest $\mathrm{B}$ coefficients in the regression equation, and, thus, statistically significant dependencies were recorded for two variables, namely, Trust in the Internet (TinI) and general Trust in Science and Technology (TST). Therefore, the Polish government, which offers solutions in the field of e-Government and wants to increase trust in such solutions, should concen- 


\section{Table 3. Results of the Test Hypotheses}

\begin{tabular}{|c|c|c|c|}
\hline Relation between Constructs & $\begin{array}{l}\text { Test statistic } \\
\text { Chi-Square }\end{array}$ & $\mathbf{P}$ & Hypothesis Testing \\
\hline H1: General Trust vs. Trust in the e-Declaration & 114.64 & $* * *$ & Support \\
\hline H2: General Trust in Science and Technology vs. Trust in the e-Declaration & 158.20 & $* * *$ & Support \\
\hline H3: Trust in the Internet vs. Trust in the e-Declaration & 237.05 & $* * *$ & Support \\
\hline H4: Internet Experience vs. Trust in the e-Declaration & 39.926 & $* * *$ & Support \\
\hline H5: Trust in e-Declaration vs. Future Intention to Use the e-Declaration & 207.73 & $* * *$ & Support \\
\hline
\end{tabular}

trate on building trust in the Internet and trust in the development of technology and science in general. Trust in the Internet is considered a critical factor in the success of e-government development [Belanger, Carter, 2008; Lee et al., 2011]. One of the tools for building trust in the Internet is SLA (Service Level Agreement) agreements defining the level of services. In Poland, for example, for the ePUAP (Electronic Platform for Public Administration Services) offering e-Government services, the SLA availability rate in 2015 was $96.38 \%$.

\section{Conclusions}

This article covers issues that are particularly important in the context of explaining the reasons for the relatively low level of digital interaction between Poles and public institutions. The share of Polish citizens engaged in digital interactions with public institutions is only $30 \%$, while in Scandinavian countries, it amounts to $88.0 \%$ in Denmark, $85.0 \%$ in Norway, and $82.0 \%$ in Finland. ${ }^{2}$ According to available Eurostat data, in 2013 , only $12.0 \%$ of Polish citizens submitted electronic tax returns, while in other countries, this indicator was as follows: Denmark - 63.0\%, Iceland $-61.0 \%$, Norway $-50.0 \%$, and Sweden $46.0 \%{ }^{3}$ The delay in this development of Polish society in relation to other Western European countries is often the cause of inappropriate comparative analyses on an international scale.

Research conducted by Alzahrani et al. confirmed that in many countries, citizens still did not trust the services provided by the government, which has a significant negative impact upon the process of its further adaptation and dissemination [Alzahrani et al., 2017]. The study aimed to show the relationship between the determinants of trust in the studied eGovernment technology and the impact of this trust upon future intentions to use e-Government technology. The author's object of interest was the technology enabling taxpayers to fill and send tax returns via the Internet (e-Declaration).

\section{Table 4. Results of Multiple Regression Analysis}

\begin{tabular}{|l|r|r|r|r|r|}
\hline \multirow{2}{*}{\multicolumn{1}{c|}{ Model }} & \multicolumn{2}{c|}{$\begin{array}{c}\text { Unstandardized } \\
\text { Coefficients }\end{array}$} & \multicolumn{2}{c|}{$\begin{array}{c}\text { Standardized } \\
\text { Coefficients }\end{array}$} & \multirow{2}{*}{ Sig. p-value } \\
\cline { 2 - 6 } & \multicolumn{1}{c|}{ B } & Standard Error & Beta & & \\
\hline Constant & 2.359 & 0.263 & 0.976 & 0.000 \\
\hline Internet Experience & 0.069 & 0.041 & 0.051 & 1.704 & 0.089 \\
\hline Trust in the Internet & 0.250 & 0.025 & 0.314 & 9.897 & 0.000 \\
\hline General Trust & 0.029 & 0.021 & 0.040 & 1.355 & 0.176 \\
\hline General Trust in Science and Technology & 0.233 & 0.035 & 0.212 & 6.641 & 0.000 \\
\hline
\end{tabular}

Model Summary:

\begin{tabular}{|c|c|c|c|c|c|c|c|}
\hline $\mathbf{R}$ & Adjusted $\mathbf{R}^{2}$ & Standard Error & df1 & df2 & Mean Square & $\mathbf{F}$ & Sig. \\
\hline 0.480 & 0.227 & 1.165 & 4 & 1041 & 106.306 & 78.373 & 0.000 \\
\hline
\end{tabular}

Dependent variable: Trust in e-Declaration. Predictors: Internet Experience, Trust in the Internet, General Trust, and General Trust in Science and Technology

Source: elaborated by the author.

\footnotetext{
2 Digital Economy and Society Index, 2017. Available at: http://ec.europa. eu/eurostat/web/digital-economy-and-society/data/database, accessed 07.08.2019.

Digital Economy and Society Database, 2017. Available at: https://ec.europa.eu/digital-single-market/en/scoreboard/poland, accessed 19.03.2019.
} 
The conducted research confirmed that the future scope of the use of e-Government solutions will be determined by the trust of the users of the proposed solutions. Ensuring a high level of security in using the Internet is a key factor shaping trust in technological solutions offered by the government.

In the context of the obtained results, future research efforts should focus on clarifying the tools of building trust in the Internet and general trust in science and technology. An important tool for building social trust in the Internet is an awareness of threats, risks, and measures to mitigate those perceived risks. User experience with the use of e-Declaration technology with a lack of undesirable or accidental events (loss of data) will gradually build trust in such technological solutions. Also, the popularity of using other ICT solutions in other areas of life will force users to use e-Declaration solutions. Unfortunately, the processes of building both interpersonal trust and trust in technology are time-consuming processes and it is often necessary to wait a few years for the expected results in behavior changes of the users.

It also indicates the direction in which technological innovation in the area of e-government should develop so that it is aligned with the Responsible Research and Innovation paradigm [Nazarko, 2016].

Research on the dynamics of changes in the level of trust in science and technology of Polish society may prove to be an interesting research topic. Currently, the relatively high level of trust of Polish society in technology and science is inversely proportional to the low level of interpersonal trust.

\section{References}

Agag G.M., El-Masry A.A. (2017) Why Do Consumers Trust Online Travel Websites? Drivers and Outcomes of Consumer Trust toward Online Travel Websites. Journal of Travel Research, vol. 56, no 3, pp. 347-369. DOI: 10.1177/0047287516643185.

Al-Hujran O., Al-Debei M.M., Chatfield A., Migdadi M. (2015) The imperative of influencing citizen attitude toward e-government adoption and use. Computers in Human Behavior, vol. 53, pp. 189-203. DOI: 10.1016/j.chb.2015.06.025.

Alzahrani L., Al-Karaghouli W., Weerakkody V. (2017) Analysing the critical factors influencing trust in e-government adoption from citizens' perspective: A systematic review and a conceptual framework. International Business Review, vol. 26, no 1, pp. 164-175. DOI: 10.1016/j.ibusrev.2016.06.004.

Belanger F., Carter L. (2008) Trust and risk in e-Government adoption. The Journal of Strategic Information Systems, vol. 17, no 2, pp. 165-176. DOI: 10.1016/j.jsis.2007.12.002.

Carter L., Bélanger F. (2005) The utilization of e-government services: Citizen trust, innovation and acceptance factors. Information Systems Journal, vol. 15, no 1, pp. 5-25. DOI: 10.1111/j.1365-2575.2005.00183.x.

Chen J.V., Jubilado R.J.M., Capistrano E.P.S., Yen D.C. (2015) Factors affecting online tax filing - An application of the IS Success Model and trust theory. Computers in Human Behavior, vol. 43, pp. 251-262. DOI: 10.1016/j.chb.2014.11.017.

Chopra K., Wallace W.A. (2003) Trust in electronic environments. Proceedings of the $36^{\text {th }}$ Annual Hawaii International Conference on System Science, Piscataway, NJ: IEEE, pp. 123-135.

Colesca S.E. (2009) Understanding Trust in e-Government. Inzinerine Ekonomika-Engineering Economics, vol. 63, no 4, pp. 1-15. Available at: http://inzeko.ktu.lt/index.php/EE/issue/view/424, accessed 24.05.2019.

Davis F.D. (1985) A Technology Acceptance Model for empirically testing new and-user information systems: Theory and results, Cambridge, MA: MIT Sloan School of Management.

Ejdys J., Halicka K. (2018) Sustainable Adaptation of New Technology - The Case of Humanoids Used for the Care of Older Adults. Sustainability, vol. 10, no 10, article 3770. Available at: https://doi.org 10.3390/su10103770, accessed 15.09.2019.

Gefen D. (2004) What makes an ERP implementation relationship worthwhile: linking trust mechanisms and ERP usefulness. Journal of Management Information Systems, vol. 21, no 1, pp. 263-288. DOI: 10.1080/07421222.2004.11045792.

Gefen D., Karahanna E., Straub D. (2003a) Trust and TAM in online shopping: An integrated model. MIS Quarterly, vol. 27, no 1, pp. 51-90. DOI: 10.2307/30036519.

Gefen D., Karahanna E., Straub D.W. (2003b) Inexperience and experience with online stores: The importance of TAM and trust. IEEE Transactions on Engineering Management, vol. 50, no 3, pp. 307-321. DOI: 10.1109/TEM.2003.817277.

Halicka K. (2019) Gerontechnology - the assessment of one selected technology improving the quality of life of older adults. Engineering Management in Production and Services, vol. 11, no 2, pp. 43-51. DOI: 10.2478/emj-2019-0010.

Hengstler M., Enkel E., Duelli S. (2016) Applied artificial intelligence and trust - The case of autonomous vehicles and medical assistance devices. Technological Forecasting \& Social Change, vol. 105, pp. 105-120. DOI: 10.1016/j.techfore.2015.12.014.

Hernández-Ortega B. (2011) The role of post-use trust in the acceptance of a technology: Drivers and consequences. Technovation, vol. 31, no 10-11, pp. 523-538. DOI: 10.1016/j.technovation.2011.07.001.

Joshi P., Shareeful I. (2018) E-Government Maturity Model for Sustainable E-Government Services from the Perspective of Developing Countries. Sustainability, vol. 10, article 1882, pp. 1-28. DOI: 10.3390/su10061882.

Kaur K., Rampersad G. (2018) Trust in driverless cars: Investigating key factors influencing the adoption of driverless cars. Journal of Engineering and Technology Management, vol. 48, pp. 87-96. DOI: 10.1016/j.jengtecman.2018.04.006.

Khalilzadeh J., Ozturk A.B., Bilgihan A. (2017) Security-related factors in extended UTAUT model for NFC based mobile payment in the restaurant industry. Computers in Human Behavior, vol. 70, pp. 460-474. DOI: 10.1016/j.chb.2017.01.001.

Komiak S.Y.X., Benbasat I.A. (2008) Two-process view of trust and distrust building in recommendation agents: A processtracing study. Journal of the Association for Information Systems, vol. 9, no 12, pp. 727-747. DOI: 10.17705/1jais.00180. 
Kumar V.V.R., Lall A., Mane T. (2017) Extending the TAM Model: Intention of Management Students to Use Mobile Banking: Evidence from India. Global Business Review, vol. 18, no 1, pp. 238-249. DOI: 10.1177/0972150916666991.

Kurfal M., Arifoglu A., Tokdemir G., Paçin Y. (2017) Adoption of e-government services in Turkey. Computers in Human Behavior, vol. 66, pp. 168-178. DOI: 10.1016/j.chb.2016.09.041.

Lankton N.K., McKnight D.H., Tripp J. (2015) Technology, Humanness, and Trust: Rethinking Trust in Technology. Journal of the Association for Information Systems, vol. 16, no 10, pp. 880-918. DOI: 10.17705/1jais.00411.

Lean K., Zailani S., Ramayah T., Fernando Y. (2009) Factors influencing intention to use e-government services among citizens in Malaysia. International Journal of Information Management, vol. 29, no 6, pp. 458-475. DOI: 10.1016/j.ijinfomgt.2009.03.012.

Lee J., Kim H. J., Ahn M.J. (2011) The willingness of e-Government service adoption by business users: The role of offline service quality and trust in technology. Government Information Quarterly, vol. 28, no 2, pp. 222-230. DOI: 10.1016/j. giq.2010.07.007.

Lee M.K.O., Turban E. (2001) A trust model for consumer internet shopping. International Journal of Electronic Commerce, vol. 6, no 1, pp. 75-91. DOI: 10.1080/10864415.2001.11044227.

Lin J., Wang B., Wang N., Lu Y. (2014) Understanding the evolution of consumer trust in mobile commerce: A longitudinal study. Information Technology and Management, vol. 15, no 1, pp. 37-49. DOI: 10.1007/s10799-013-0172-y.

Lippert S.K., Swiercz P.M. (2005) Human resource information systems (HRIS) and technology trust. Journal of Information Science, vol. 31, no 5, pp. 340-353. DOI: 10.1177/0165551505055399.

Lippert S.K. (2007) Investigating Postadoption Utilization: An Examination Into the Role of Interorganizational and Technology Trust. IEEE Transactions on Engineering Management, vol. 54, no 3, pp. 468-483. DOI: 10.1109/TEM.2007.900792.

McKnight D.H., Cummings L.L., Chervany N.L. (1998) Initial trust formation in new organizational relationships. Academy of Management Review, vol. 23, no 3, pp. 473-490. Available at: https://www.jstor.org/stable/259290, accessed 09.06.2019.

Meng D., Min Q., Li Y. (2008) Study on trust in mobile commerce adaptation - A conceptual model. Proceedings of the 2008 International Symposium on Electronic Commerce and Security, 3-5 August, Guangzhou City, China, Piscataway, NJ: IEEE, pp. 246-249. Available at: https://doi.org/10.1109/ISECS.2008.54, accessed 12.11.2018.

Nazarko J., Ejdys J., Halicka K., Magruk A., Nazarko Ł., Skorek A. (2017) Application of Enhanced SWOT Analysis in the Future-oriented Public Management of Technology. Procedia Engineering, vol. 182, pp. 482-490. DOI: 10.1016/j.proeng.2017.03.140.

Nazarko L. (2016) Responsible Research and Innovation - A New Paradigm of Technology Management. Paper presented at the 9th International Scientific Conference "Business and Management 2016", Vilnius Gediminas Technical University. May 12-13, 2016. DOI: 10.3846/bm.2016.71.

Nazarko L. (2017) Future-Oriented Technology Assessment. Procedia Engineering, vol. 182, pp. 504-509. DOI: 10.1016/j. proeng.2017.03.144.

Pavlou P., Fygenson M. (2006) Understanding and predicting electronic commerce adoption: An extension of the theory of planned behavior. MIS Quarterly, vol. 30, no 1, pp. 115-143. DOI: 10.2307/25148720.

Rousseau D.M., Sitkin S.B., Burt R.S., Camerer C. (1998) Not so different after all: A cross-discipline view of trust. Academy of Management Review, vol. 23, no 3, pp. 393-403. DOI: 10.5465/amr.1998.926617.

Tams S., Thatcher J. B., Craig K. (2018) How and why trust matters in post-adoptive usage: The mediating roles of internal and external self-efficacy. Journal of Strategic Information Systems, vol. 27, pp. 170-190. DOI: 10.1016/j.jsis.2017.07.004.

Venkatesh V., Thong J.Y., Xu X. (2012) Consumer acceptance and use of information technology: Extending the unified theory of acceptance and use of technology. MIS Quarterly, vol. 36, no 1, pp. 157-178. DOI: 10.2307/41410412.

Voutinioti A. (2013) Determinants of User Adoption of e-Government Services in Greece and the role of Citizen Service Centres. Procedia Technology, vol. 8, pp. 238-244. Available at: https://doi.org/10.1016/j.protcy.2013.11.033, accessed 08.08.2019.

Weerakkody V., El-Haddadeh R., Al-Sobhi F., Shareef M.A., Dwivedi Y.K. (2013) Examining the influence of intermediaries in facilitating e-government adoption: An empirical investigation. International Journal of Information Management, vol. 33, no 5, pp. 716-725.

Williams M.D., Rana N.P., Dwivedi Y.K. (2015) The unified theory of acceptance and use of technology (UTAUT): A literature review. Journal of Enterprise Information Management, vol. 28, no 3, pp. 443-488. DOI: 10.1108/JEIM-09-2014-0088.

Wu K., Zhao Y., Zhu Q., Tan X., Zheng H. (2011) A meta-analysis of the impact of trust on technology acceptance model: Investigation of moderating influence of subject and context type. International Journal of Information Management, vol. 31, no 6, pp. 572-581. DOI: 10.1016/j.ijinfomgt.2011.03.004.

Zhou T. (2011) An empirical examination of initial trust in mobile banking. Internet Research, vol. 21, no 5, pp. 527-540. DOI: $10.1108 / 10662241111176353$. 